\title{
Utilization Plan of Underground River in Dry Area
}

\author{
Agus Panca Adi Sucahyo and Waterman Sulistyana Bargawa \\ Department of Mining Engineering, University of Pembangunan Nasional Veteran Yogyakarta, Yogyakarta 55283, Indonesia
}

\begin{abstract}
Groundwater from underground rivers is one of the potential raw water sources in the karst area. Research to exploit the potential sources of water from underground rivers in karst areas is very important. Utilization of water resources should be based on technique, environmental and social conditions. The problems are to find the groundwater river flows, to design a well installation, to determine the feasibility, and to manage the water use. Analysis of the results of geological mapping, topography, geophysical measurements, drilling, pipeline and electrical survey, and pumping tests produce the feasibility of the water utilization. Geoelectric data indicates there is a saturated zone at a depth of about 70-90 $\mathrm{m}$ from the surface. Well construction is implemented by using a 83 $\mathrm{m}$ PVC (Polyvinyl Chloride) pipe and a $15 \mathrm{~m}$ screen length. The groundwater level remains stable even though it has been pumped with a maximum discharge of 5 liters/sec. Based on the elevation difference from topographic mapping results, the number of booster pumps can be calculated. Utilization of water from underground rivers can overcome the problem of water shortage in dry area.
\end{abstract}

Key words: Geological mapping, underground river, dry area, karst, water quality.

\section{Introduction}

Geological research is mostly done in dry areas, such as karstic geomorphology [1-5], and studies on the development and utilization of karst areas [6, 7]. Other studies are models of conservation of the karst area $[8,9]$. In the dry season, people living in arid regions need clean water supplies. Doline ponds have an important role as one of water resources in karst areas, especially during dry seasons [10, 11]. Many studies in the karst area of anticipatory action are providing permanent water supplies [12]. Groundwater from underground rivers is one of the potential raw water sources in the karst area. Research is often conducted to identify hydrogeological conditions as a reference in preparing water source utilization plans in a dry prone area [13-15]. Research on ground water potential through hydrogeological surveys is used to determine groundwater sources by evaluating geoelectric data to determine the location of production wells [16, 17]. Utilization of groundwater potential is based on groundwater quality analysis and environmental sustainability functions.

Corresponding author: Waterman Sulistyana Bargawa, Ph.D., senior lecturer, research field: mining environment.
Pumping test on hydrogeological research is conducted to analyze the potency of groundwater as raw water source [18].

Research to exploit the potential sources of water from underground rivers in karst areas is very important. Utilization of water resources should be based on social and environmental conditions. This case study was conducted in Central Java Province of Indonesia (Fig. 1). The primacy of research in this area is the potential of natural disasters related to geological hazards include: (a) landslides of rock and erosion that potentially occur on the slopes of limestone hill; (b) drought hazard potentially occurs in the southern research area. An interesting water potential for this steep coastal area is the emergence of an underground river stream that mixes with seawater (Fig. 2), but there is no cave in the area. The difference in elevation is quite large that is about $90 \mathrm{~m}$, it makes a problem on the utilization of clean water potential.

\section{Objective}

The objectives of the study were (a) to analyze hydrogeological conditions, and to plan the utilization of potential water sources to meet the community's 


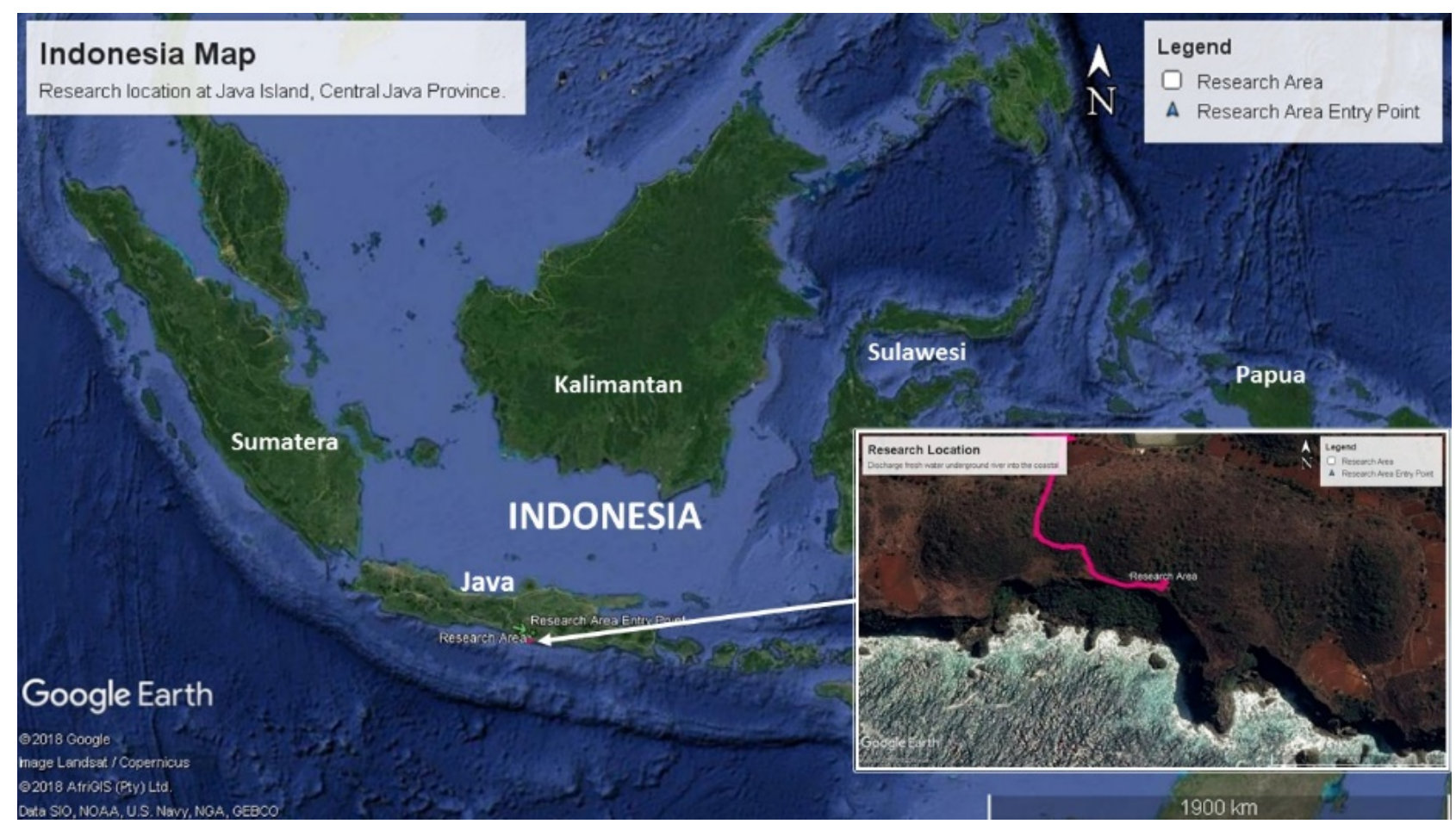

Fig. 1 Research location in Central Java Province of Indonesia to exploit potential water source from underground river in karst area.

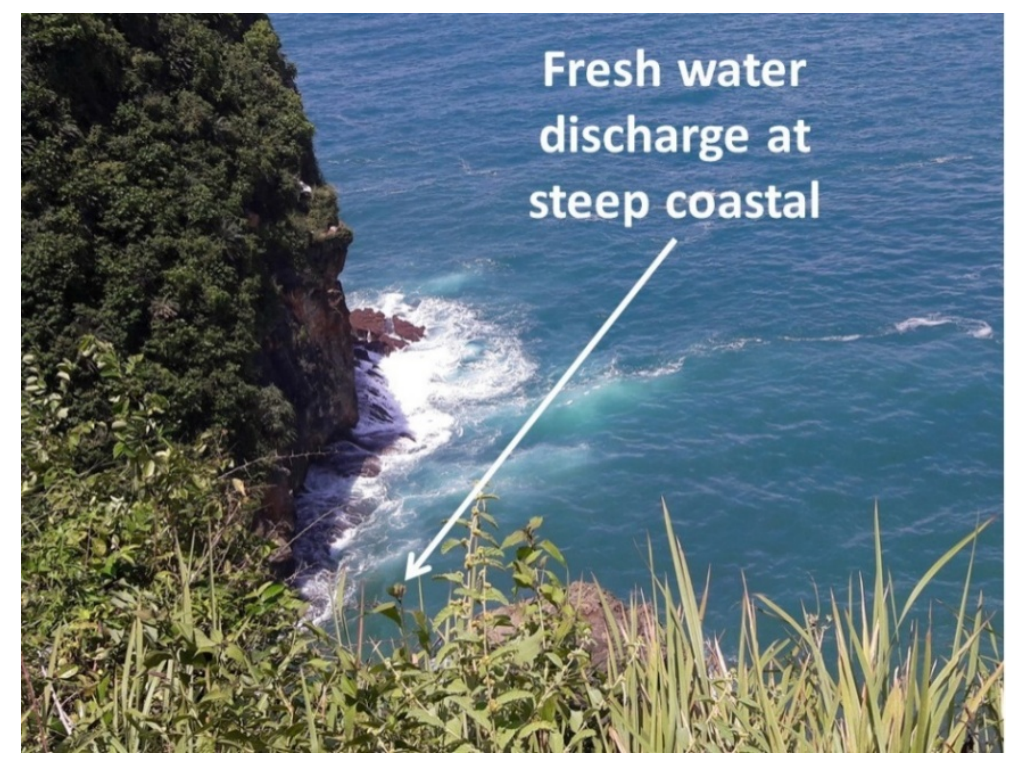

Fig. 2 Underground river stream that mixes with seawater.

water needs in dry prone areas; (b) to design the utilization of water source of underground river in accordance with hydrogeological condition of study area.

\section{Methods and Material}

Based on the survey, the population in the study area is 2,711 people. During the dry season, this area is always lack of clean water. The research methodology includes: (a) topographic mapping, surface geology and underground geology; (b) pipe and electricity network and distribution survey; (c) geoelectric survey; (d) drilling and logging; (e) construction of well; (f) pumping test; (g) analysis of water samples; (h) social 
and community environmental surveys. Geological mapping is intended to collect various data, surface and subsurface geological information covering the distribution and physical properties of soil or rocks, groundwater conditions, morphology and geological hazards. Geoelectric method for analyzing groundwater potential using resistivity meter with configuration of Wenner-Schlumberger. And the determination of drilling location is based on the interpretation of field geology data and geoelectric measurement data. The purpose of logging is to determine the physical quantities of the rock based on the physical properties of the rock.

Well construction includes the installation of casing and screen pipe in accordance with the design of the production well construction. Well construction planning is carried out to a depth of $90 \mathrm{~m}$. The water from the well flows into the tubs and then flows to the surrounding community. The purpose of this pumping test is to examine the condition of underground river flow and deep well type capacity, so that it can be determined the type and capacity of the pump to be installed. Groundwater quality tests include temperature, $\mathrm{pH}$ and electrical conductivity, while laboratory tests include physical, chemical and metal content to ensure that water quality is safely consumed by the community. Important aspect in this research is calculation of diameter and length of pipe, flow velocity, selection and calculation of pump. The pump is expected to generate optimum debit with maximum efficiency.

Pipe diameter and flow velocity are important factors in the pumping system. The discussion follows the equation given by Ref. [19, 20]. Calculation of two parameters using Eq. (1):

$$
D_{i}=3.9 \times Q^{0.45} \times \rho^{0.13}
$$

where $D_{i}$ : pipe inner diameter, $\mathrm{mm}$ or inch; $Q$ : capacity/debit, $\mathrm{m}^{3} / \mathrm{hr}$. or liter/min; $\rho$ : density of fluid, $\mathrm{kg} / \mathrm{m}^{3}$.

Calculation of fluid flow velocity:

$$
V=\frac{Q}{A}
$$

where $V$ : fluid flow velocity, $\mathrm{m} / \mathrm{sec} ; Q:$ debit /capacity, $\mathrm{m}^{3} / \mathrm{hr}$. or liter/min; $A$ : surface area, $\mathrm{m}^{2}$.

Other aspects considered are (a) the total head includes the pump's static head, the head loss on the pipe, the friction loss, and the shock loss; (b) the velocity head arising from the speed of the water flow in the pipe, both suction and discharge. Calculation of high-pressure static head using Eq. (3):

$$
h_{s}=t_{2}-t_{1}
$$

where $h_{s}$ : high press static pump; $t_{2}$ : water elevation in the outlet; $t_{l}$ : water elevation in the suction pipe. The velocity head formula is Eq. (4):

$$
h_{v}=\frac{v^{2}}{2 g}
$$

where $h v$ : velocity head, $\mathrm{m} ; v$ : the water velocity in the pipe, $\mathrm{m} / \mathrm{sec} ; \mathrm{g}$ : the force of gravity. Head loss consists of friction loss and sock loss. Generally, the pipe-producing factory publishes the pipe friction handbook, whereas for the calculation of shock loss using Eqs. $(5,6)$ [21, 22]:

$$
\begin{array}{r}
H F=H L \times L_{\text {pipe }} \\
H L=\left[\frac{3.35 \times 10^{6} \times Q}{d^{2.63} \times C}\right]^{1.852}
\end{array}
$$

where $H F_{\text {pipe }}$ : pipe friction loss, m; $L_{\text {pipe }}$ : pipe length, m; $H L$ : pipe head loss, m; $Q$ : pump debit, liter/sec; $d$ : pipe inner diameter, $\mathrm{mm}$ or inch; $C$ : Hazen William's constant. The total pump head is the sum of all head loss and is expressed in Eq. (7):

$$
H_{t}=h_{s}+h_{v}+H_{f}+H_{f s}
$$

Calculation of pump power using Eq. (8):

$$
P_{p}=1.02 \times Q \times H_{t} \times S G \times E_{f}
$$

where $P p$ : power pump, kW; $Q$ : pump discharge, $\mathrm{m} / \mathrm{sec} ; H t$ : total head, $\mathrm{m} ; S G$ : density of water; $E f$ : pump efficiency, \%. The pump used in the well is a submersible pump. Electricity network and distribution surveys are needed to determine the potential state of power distribution that is useful to assist the design process of utilizing the underground water source.

Social and community environmental surveys are needed to identify demographic data of research area 
such as population, occupation, culture and community environment. Social and environmental surveys to support the sustainability of underground river water use are contextually adapted to the conditions of the communities in the study area. Development of drinking water from water sources, raw water drainage, drinking water treatment, distribution network to home connections is implemented taking into account the rules and norms of environmental sustainability. Based on studies conducted by Kevany, K., and Huisingh, D. [23] involving women in the development process from planning, implementing and managing water supply and sanitation facilities proved to improve the sustainability of water and sanitation infrastructure.

\section{Results}

Based on the results of geological mapping, the research area is included in the geological unit of karst hillside environment. This unit forms a coarse rough morphology, and a steep slope. Limestone in this morphology is formed of karst natural phenomena. The process of dissolving limestone causes the cavity within the limestone. The formation of cavities is the initial process of forming the underground river basin. The underground river stream eventually emerges as a spring and empties into the Indian Ocean. Geoelectric data indicates there is a saturated zone (aqueous cavity) at a depth of about $70-90 \mathrm{~m}$ from the surface. Implementation of drilling activities with a depth of $90 \mathrm{~m}$ is based on the geoelectric data. In drilling activities, the water indicated to rise at a depth of $68 \mathrm{~m}$ and the estimated depth of the base of the underground river is $83 \mathrm{~m}$. Based on underground river research, water flows from north to south. Water enters karst fracture directly, flows up into a basin, and becomes an underground river. Water continues to flow down and has no phreatic level which is homogeneous as in non-karst aquifers.

Well construction is implemented by using a $83 \mathrm{~m}$ PVC pipe and a $15 \mathrm{~m}$ screen length. Based on the test results, groundwater table was found at depth of $68 \mathrm{~m}$ (28 $\mathrm{m}$ a.s.1). Based on drilling results, the saturation zone thickness is $15 \mathrm{~m}$, and the lowest saturation zone is at $83 \mathrm{~m}$ (13 $\mathrm{m}$ a.s.l). The pumping test results show a $3 \mathrm{~m}$ groundwater level decrease, then the submersible pump installation is carried out at a depth of $74 \mathrm{~m} \mathrm{(22} \mathrm{m}$ a.s.l). The data recorded in the pumping test are (a) preliminary groundwater level (pizometric baseline); (b) pumping flow; (c) groundwater advance during draw-down; (d) time of pumping start; (e) time after the pump is turned off. Based on the results of the pumping test, the groundwater level remains stable even though it has been pumped with a maximum discharge of 5 liters/sec.

The total population in the research area is 2,711 people. If the water debit is 5 liters/sec, while the assumption of the pump's working time is $10 \mathrm{hr} / \mathrm{day}$, the water produced is 180,000 liters/day. If the water requirement is assumed to be 60 liters/day/person (Regulation of the Minister of Home Affairs No. 23 of 2006), then about 3,000 people can use clean water. Utilization of water from underground rivers can overcome the problem of water shortage in arid area such as in research area. Based on the elevation difference from topographic mapping results, the number of booster pumps can be calculated. The total length of the pipeline is $5,544 \mathrm{~m}$. This pipe network is divided into 12 segments that require 4 booster pumps; in other areas, the water flow uses the force of gravity. Based on the results of the lane survey, and field data analysis for the water source utilization plan, requires the addition of new power lines. Planning for distribution of electricity network is MVN (Medium Voltage Network) and LVN (Low Voltage Network). The total length of the medium voltage network is $2,080 \mathrm{~m}$ and the total length of the low-voltage network is $210 \mathrm{~m}$.

Water quality testing from underground river is based on Regulation of Minister of Health Republic of Indonesia No. 492 of 2010 . Test results on water from 
the underground river classified on drinking water through the processing. Parameters that require special attention for the initial treatment are organic and inorganic chemicals. The organic material contained in water is a detergent content that shows a value above the maximum allowable level of $329.7 \mathrm{mg} /$ liter (more than $0.05 \mathrm{mg} /$ liter). An-organic chemical parameters such as cadmium need to be treated. Actually, in the research area, there is a lokva (the small karts lake situated in limestone area), but the water quality is very bad. Infrastructure and drinking water facilities cannot be utilized optimally. The lack of community involvement in planning, construction, operation and maintenance activities resulted in non-optimal water utilization. In addition, the non-contextual choice of technology makes it difficult for people to determine the infrastructure and facilities according to the needs, local culture, the ability of communities to manage infrastructure and local physical conditions. Lack of community involvement also makes the infrastructure and facilities of drinking water unsustainable, unable to function properly, as well as the lack of public attention to maintain the sustainability of infrastructure and facilities.

Investments in infrastructure and facilities for drinking water and environmental sanitation which have been supply-driven oriented, have had an impact on the low effectiveness of existing infrastructure and facilities. The change of management paradigm in this research is focused on the management of facilities and infrastructure. This management involves the whole society of users. Involvement in decision making results in greater community participation in implementation and maintenance. The development of drinking water services by engaging the community contextually has better effectiveness and sustainability. Making the community as a decision maker means positioning the community as the main responsibility in the service of drinking water and environmental sanitation. Community involvement at each stage is an effort to increase community ownership of drinking water infrastructure and facilities. This is an effort to change society behavior gradually. The sense of belonging from the community generates awareness in maintaining the sustainability of water resources. This study encourages community participation in financing the development of water supply and sanitation infrastructure and develops community empowerment systems to manage, control and direct financial resources.

Contextual management is the highest decision making of all aspects related to drinking water and or environmental sanitation. The water management is from early stages of identification of drinking water needs, technical planning, and development implementation. In the research area, the role of women is very dominant to meet the needs of drinking water and environmental sanitation. As a party related to the utilization of drinking water and sanitation infrastructure, women are more aware of what they need in terms of access to water and ease of use of infrastructure and facilities. In this study, women are the main roles in the development of drinking water and environmental sanitation. Placing women as the main roles is defined as their active participation in identifying basic issues of drinking water and sanitation.

The following is the cost of water utilization of underground river: the cost of drilling activities for groundwater use is US\$ $11,264.00$; construction of pipe network and pump installation at production wells US\$ $34,545.00$; plans for adding new electricity network US\$28,788.00. Total cost of utilizing water source is US\$74,597.00. Success indicators are appropriate technology, acceptable projects, facility maintenance, encouraging active participation in finances, women are involved in every stage of the project. The fulfillment of success indicators can ensure the sustainability.

\section{Conclusion}

Based on the discussion above, some conclusions 
can be noted: (a) Based on geoelectric measurement, saturated zone is at depth of 70-90 m. Groundwater is found at a depth of $68-83 \mathrm{~m}$, therefore the installation of a submersible pump at a depth of $74 \mathrm{~m}$. The construction of wells is implemented by using a pipe of $83 \mathrm{~m}$ PVC and $15 \mathrm{~m}$ long screen; (b) Based on the pumping test resulting in a maximum debit of 5 liters/sec, it provides a source of clean water for 2,711 inhabitants living in the arid region; (c) detergent and cadmium content require a special attention. The treatment of the water is required before consumption in order to safeguard human health.

\section{References}

[1] Martel, R., Castellazzi, P., Gloaguen, E., Trépanier, L., and Garfias, J. 2018. "ERT, GPR, InSAR and Tracer Tests to Karst Aquifer Systems under Urban Areas: The Case of Quebec City." Geomorphology 310: 45-56.

[2] Szczygieł, J., Golicz, M., Hercman, H., and Lynch, E. 2018. "Geological Constraints on Cave Development in the Plateau-gorge Karst of South China." Geomorphology 304: 50-63.

[3] Hofierka, J., Gallay, M., Bandura, P., and Šašak, J. 2018. "Identification of Karst Sinkholes in a Forested Karst Landscape Using Airborne Laser Scanning Data and Water Flow Analysis." Geomorphology 308: 265-77.

[4] Tîrlă, L., and Vijulie, I. 2018. "Structural-Tectonic Controls and Geomorphology of the Karst Corridors in Alpine Limestone Ridges: Southern Carpathians Romania." Geomorphology 197: 123-36.

[5] Labat, D., and Mangin, A. 2105. "Transfer Function Approach for Artificial Tracer Test Interpretation in Karstic Systems." Journal of Hydrology 529: 866-71.

[6] Niemiller, M. L., Zigler K. S., and Stephen, C. D. R. 2016. "Vertebrate Fauna in Caves of Eastern Tennessee within the Appalachians Karst Region USA.” Journal of Cave and Karst Studies 78 (1): 1-24.

[7] Veni, G. A. 1999. "Geomorphological Strategy for Conducting Environmental Impact Assessments in Karst Areas." Geomorphology 31 (1-4): 151-80.

[8] Epting, J., Page, R. M., Auckenthaler, A., and Huggenberger, P. 2018. "Process-based Monitoring and Modeling of Karst Springs-Linking Intrinsic to Specific Vulnerability." Science of The Total Environment 625: 403-15.

[9] Liao, C., Yue, Y., Wang, K., Fensholt, R., and Brandt, M. 2018. "Ecological Restoration Enhances Ecosystem Health in the Karst Regions of Southwest China."
Ecological Indicators 90: 416-25.

[10] Widyastuti, M., and Haryono, E. 2016. "Water Quality Characteristics of Telaga Jonge as Water Resources for the People of Semanu District Gunungkidul Regency." Indonesian Journal of Geography 48 (2): 428-38.

[11] Li, X. Y., Contreras, S., and Bennet, A. S. 2007. "Spatial Distribution of Rock Fragments in Dolines: A Case Study in a Semiarid Mediterranean Mountain-range." Catena 70 (3): 366-74.

[12] Plagnes, V., and Bakalowicz, M. 2002. "The Protection of a Karst Water Resource from the Example of the Larzac Karst Plateau: A Matter of Regulations or a Matter of Process Knowledge?" Engineering Geology 65 (2-3): 107-16.

[13] Nsiah, E., Adjei, E. K. A., and Adjei, K. A. 2018. "Hydrogeological Delineation of Groundwater Potential Zones in the Nabogo Basin, Ghana." Journal of African Earth Sciences 143: 1-9.

[14] Acero, P., Auqué, L. F., Galve, J. P., Gutiérrez, F., and Gómez, J. B. 2015. "Evaluation of Geochemical and Hydrogeological Processes by Geochemical Modeling in an Area Affected by Evaporite Karstification.” Journal of Hydrology 529 (3): 1874-89.

[15] Wilhite, D. A., Sivakumar, M. V. K., and Pulwarty, R. 2014. "Managing Drought Risk in a Changing Climate: The Role of National Drought Policy." Weather and Climate Extremes 3: 4-13.

[16] Mogaji, K. A. 2016. "Geoelectrical Parameter-based Multivariate Regression Borehole Yield Model for Predicting Aquifer Yield in Managing Groundwater Resource Sustainability." Journal of Taibah University for Science 10 (4): 584-600.

[17] Alabi1, O. O., Ojo, A. O., and Akinpelu, D. F. 2016. "Geophysical Investigation for Groundwater Potential and Aquifer Protective Capacity." American Journal of Water Resources 4 (6): 137-43.

[18] Nassimi, A., and Mohammadi, Z. 2016. "Comparison of the Results of Pumping and Tracer Tests in a Karst Terrain." Journal of Cave and Karst Studies 78 (2): $110-8$.

[19] Hadwan, M., and Alkholidi, A. 2018. "Assessment of Factors Influencing the Sustainable Performance of Photovoltaic Water Pumping Systems." Renewable and Sustainable Energy Reviews 92: 307-18.

[20] Silaipillayarputhur, K., Al-Muhaysh, K., and Yahya, Al O. 2016. "Design of a Dowtherm a Pumping System." IJAER 11 (1): 265-72.

[21] Atoyebi, A. A., Akinnuli, B. O., and Ajobo, J. A. 2015. "Total Dynamic Head Determination Model for Submersible Pumps Installation." International Journal of Applied Science and Technology 5 (1): 95-102. 
[22] Wu, Q., Tu, K., Sun, H., and Chen, C. 2018. "Investigation on the Sustainability and Efficiency of Single-well Circulation Groundwater Heat Pump Systems." Renewable Energy 130: 656-66.
[23] Kevany, K., and Huisingh, D. 2013. "A Review of Progress in Empowerment of Women in Rural Water Management Decision-making Processes." Journal of Cleaner Production 60: 53-64. 